\title{
Degradation of Paracetamol by Photolysis Using C-N-codoped $\mathrm{TiO}_{2}$
}

\author{
Vanny Yulia Safitri ${ }^{1}$, Adlis Santoni ${ }^{2}$, Diana Vanda Wellia ${ }^{3}$, Khoiriah, $^{1}$ dan Safni ${ }^{1}$ * \\ ${ }^{1}$ Laboratory of Applied Analytical Chemistry, Department of Chemistry, Faculty of Mathematics and Natural \\ Sciences, Andalas University, Kampus Limau Manis, Padang, 25163, Indonesia \\ ${ }^{2}$ Laboratory of Organic Chemistry, Department of Chemistry, Faculty of Mathematics and Natural Sciences, \\ Andalas University, Kampus Limau Manis, Padang, 25163, Indonesia \\ ${ }^{3}$ Laboratory of Material Chemistry, Department of Chemistry, Faculty of Mathematics and Natural Sciences, \\ Andalas University, Kampus Limau Manis, Padang, 25163, Indonesia
}

*Corresponding author : safni@yahoo.com

Received August 21, 2017; Accepted November 16, 2017; Available online November 30, 2017

\begin{abstract}
Paracetamol is generally used as analgesic and antipyretic drugs. Contamination paracetamol in the environment can occur because of waste material disposal from production site and immediate disposal of household that cause water pollution. Paracetamol is degraded by photolysis method under irradiation 10 watt UV-light $(\lambda=365 \mathrm{~nm}$ ), visible-light (Philips LED 13 watt 1400 lux) and solar-light with and without addition $\mathrm{C}-\mathrm{N}$-codoped $\mathrm{TiO}_{2}$ catalyst. The solution is analyzed by UV-Vis spectrophotometer at $\lambda 200-400 \mathrm{~nm}$. Optimum weight of C-N-codoped $\mathrm{TiO}_{2}$ catalyst obtained is $20 \mathrm{mg}$ under UV-light photolysis. Paracetamol $4 \mathrm{mg} / \mathrm{L}$ is degraded $45.48 \%$ after 120 minutes under UV-light irradiation without catalyst, and increases to be $69.31 \%$ by using $20 \mathrm{mg}$ catalyst. While degradation percentage of paracetamol is $16.96 \%$ without catalyst, the percentage increases to be $34.29 \%$ after using $20 \mathrm{mg}$ catalyst for 120 minutes photolysis under visible-light. Degradation of paracetamol by solar light achieves only $12.27 \%$ in absance of catalyst for 120 minutes irradiation, but it increases significantly until $70.39 \%$ in presence of $20 \mathrm{mg}$ catalyst.
\end{abstract}

Keywords : C-N-codoped $\mathrm{TiO}_{2}$, Paracetamol, Photolysis

\section{INTRODUCTION}

Paracetamol is an extremely popular analgesic pharmaceutical product which is purchased freely. It is produced in large quantities. The amount of paracetamol produced annually is about 145,000 tons per year (Sebastine and Wakeman, 2003). The larger number of paracetamol produced each year the more waste generated, and the higher paracetamol residue in the water. Paracetamol has been found up to $6 \mu \mathrm{g} / \mathrm{L}$, and up to $10 \mu \mathrm{g} / \mathrm{L}$ in European STP effluents and in natural waters in USA respectively (Jallouli, Elghniji, Trabelsi, and Ksibi, 2017). Generally it is detected about $0.01-0.3 \mathrm{mg} / \mathrm{L}$ in the aquatic environment (Desale, Kamble, and Deosarkar, 2013). The residues of paracetamol in environment are from household sewer systems, hospital effluents, agricultural run-offs, manufacturing process, livestock, and disposal of unused and expired products are sources of paracetamol (Mameri, Debbache, Benacherine, Seraghni, and Sehili, 2016). Its continuous input may pollute water environment, decline water quality, contaminate the aquatic organisms and also can be a potential risk for aquatic and terrestrial organisms in the long term.
Advanced oxidation processes (AOPs) including heterogeneous photocatalysis is an effective technique reported for degrading drug waste in waters because semiconductors are inexpensive and capable of mineralizing various refractory compounds. The main goal of this waste treatment is to produce harmless, environmentally friendly products such as $\mathrm{CO}_{2}$ and $\mathrm{H}_{2} \mathrm{O}$ (Anggraini, Safni, Wellia, and Khoiriah, 2016; Morikawa, Asahi, Ohwaki, Aoki, Taga, 2001).

Titania $\left(\mathrm{TiO}_{2}\right)$, a heterogeneous photocatalyst, is efficient to degrade organic pollutants. This semiconductor catalyst has a band gap value about $3.2 \mathrm{eV}$ that only can be activated in higher energy like ultraviolet irradiation. One of the steps to decrease its bad gap is by doping Titania with other elements. Nitrogen and carbon are the good dopant for minimizing the band gap of $\mathrm{TiO}_{2}$ and this modification able to be activated in low energy like visible-light (Xu et al, 2011; Safni et al, 2016).

Several studies have reported using a C-N-codoped $\mathrm{TiO}_{2}$ catalyst on dyes degradation. The study included Direct Red 23 and Direct Violet (Safni et al, 2016), Yellow GCN (Safni, Wellia, Komala, and Reza, 2015) by photolysis under UV-light, visible-light and 
solar-light. In our previous research, paracetamol was degraded by photolysis under solar-light, UV-light and ozonolysis using $\mathrm{N}$-doped $\mathrm{TiO}_{2}$ catalyst. In this study, the degradation of paracetamol is by photolysis under UV-light $(\lambda=365 \mathrm{~nm})$, visible-light and solar-light by using C-N-codoped $\mathrm{TiO}_{2}$ catalyst. The effect of catalyst mass, irradiation time and energy source are investigated.

\section{EXPERIMENTAL SECTION}

\section{Research Tools and materials}

The tools used include ultraviolet-visible Spectrophotometer (Thermo Scientific Evolution 201 UV-Vis Spectrophotometer), HPLC (Shim-pack, SHIMADZU corparation, Kyoto) packed with CLC-ODS(M) 15CM column and UV detector, analytical balance (AA-200, Denver Instrument Company), UV Lamp 10 watt $(\lambda=365 \mathrm{~nm})$, Visible lamp (Philips LED 13 watt 1400 Lux), centrifuge (NASCO with speed $3000 \mathrm{rpm}$ ), and glasses equipments.

The materials used in this study are generic paracetamol $500 \mathrm{mg}$ tablets (indofarma production, Bekasi-Indonesia), titanium (III) chloride (purity > 99\%) and ammonia solution $(25 \%)$ were purchased from Merck. Sodium hydroxide and hydrogen peroxide $(30 \%)$ were purchased from Sigma. Black carbon (10 mesh) was from coconut shell. The powder C-N-codoped $\mathrm{TiO}_{2}$ catalyst was prapared Peroxo-gel method (Xu, 2011) using titanium (III) chloride, ammonia solution, and black carbon as precursor of titania, nitrogen and carbon precursors consecutively.

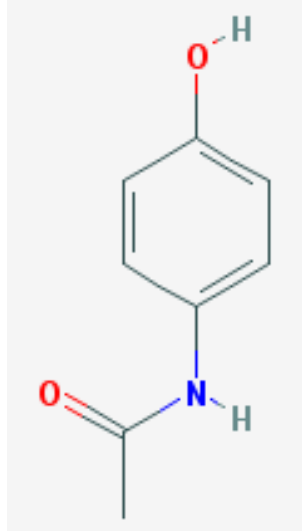

Figure 1. Stucture of paracetamol

\section{Research Methods}

Preparation and measurement of paracetamol solution by $U V$-Vis spectrophotometer

Stock solution $100 \mathrm{mg} / \mathrm{L}$ of paracetamol is prepared by dissolving 0.012 grams of

paracetamol tablet with $\mathrm{NaOH} 0.1 \mathrm{~N}$ up to 100 $\mathrm{mL}$ volume. The solution is further diluted by sodium hydroxide to get working solution with concentration 2, 4, 6, 8, $10 \mathrm{mg} / \mathrm{L}$. The absorbance of solution is measured by UV-Vis spectrophotometer at wavelength $200-400 \mathrm{~nm}$. The data is taken at the wavelength that gives maximum absorbance.

\section{Effect of catalyst mass on paracetamol degradation}

$20 \mathrm{~mL}$ solution of paracetamol $4 \mathrm{mg} / \mathrm{L}$ is loaded into the petridish. Each solution is added 5-25 mg C-N-codoped $\mathrm{TiO}_{2}$ catalyst and irradiated under UV lamp for 120 minutes. The degraded solution is centrifuged for 15 minutes to separate the catalyst from the solution. The absorbance of each solution is measured by a UV-Vis spectrophotometer at a wavelength of $257 \mathrm{~nm}$

\section{Effect of irradiation time on paracetamol degradation}

$20 \mathrm{~mL}$ solution of $4 \mathrm{mg} / \mathrm{L}$ paracetamol is degraded by photolysis with the addition of catalyst and without catalyst under radiation of UV light source $(\lambda=365 \mathrm{~nm})$, visible-light, and solar-light for 30-120 minutes. The C-N-codoped $\mathrm{TiO}_{2}$ catalyst is separated from solution by centrifuging for 15 minutes at 3000 rpm. The differences between initial and final absorbance of solution are detected by a UV-Vis spectrophotometer and indicated the percentage of paracetamol.

\section{Analysis of paracetamol solution by HPLC}

A paracetamol solution $4 \mathrm{mg} / \mathrm{L}$ is loaded into petridish and added $20 \mathrm{mg}$ of C-N-codoped $\mathrm{TiO}_{2}$ catalyst. The solution is irradiated under UV lamp $(\lambda=365 \mathrm{~nm})$ for 120 minutes. Irradiated solution and non- irradiated solution are analyzed by HPLC.

\section{RESULTS AND DISCUSSION}

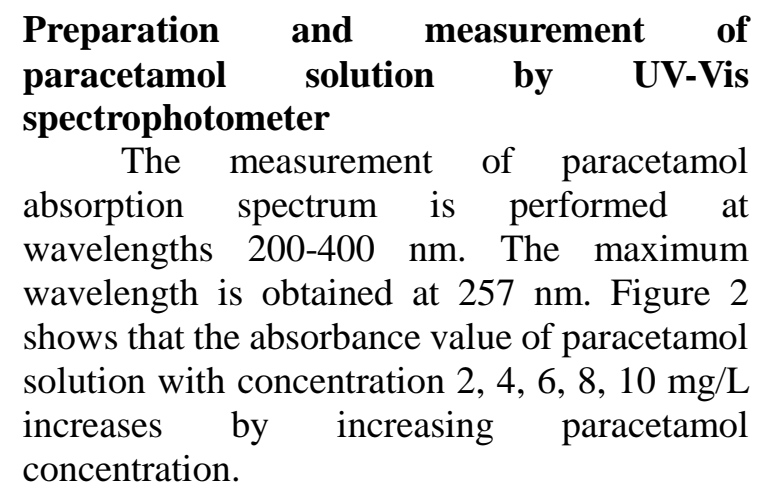




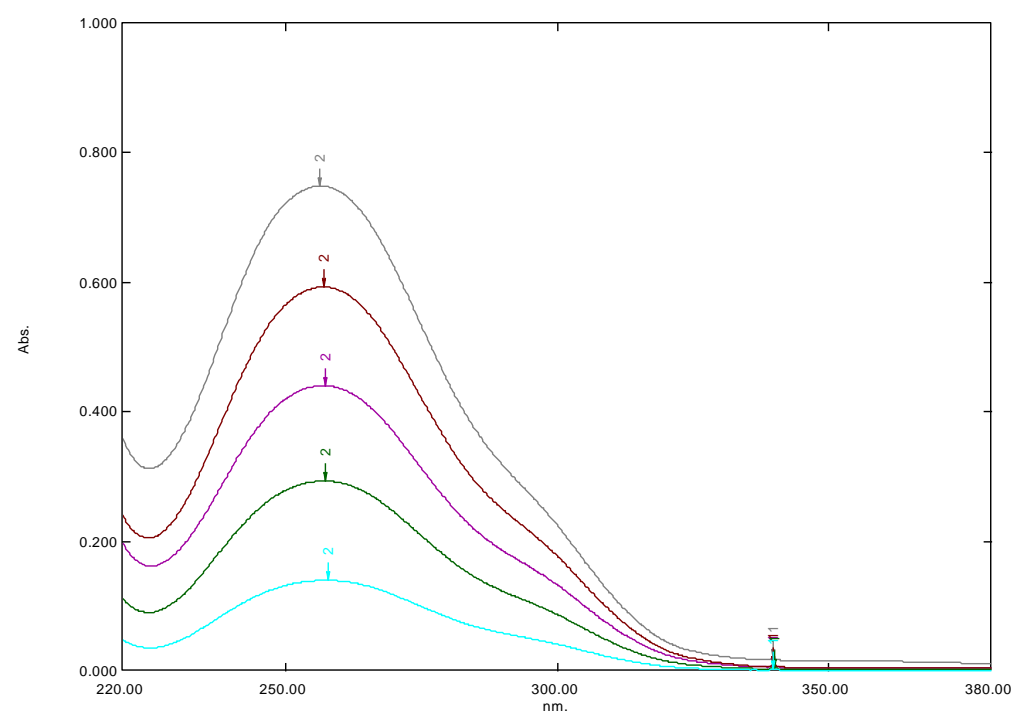

Figure 2. The absorbance spectra of paracetamol with variation concentration $2,4,6,8,10 \mathrm{mg} / \mathrm{L}$

Based on Lambert Beer's law, a good absorbance value for measuring sample solution with UV-Vis spectrophotometer is in range from $0.2-0.8$. Therefore for the next research used $4 \mathrm{mg} / \mathrm{L}$ paracetamol solution which gives the absorbance value 0.277 .

\section{Effect of catalyst mass on paracetamol degradation}

The effect of catalyst mass on paracetamol degradation is investigated by varying the weight of the $\mathrm{C}-\mathrm{N}$-codoped $\mathrm{TiO}_{2}$ catalyst $5,10,15,20$ and $25 \mathrm{mg}$. Figure 3 shows the relationship between percent degradation and the weight of the $\mathrm{C}-\mathrm{N}$-codoped $\mathrm{TiO}_{2}$ catalyst. The degradation percentage of paracetamol increases with increasing the number of catalysts from $10 \mathrm{mg}$ to $20 \mathrm{mg}$ with efficiency removal 46.2-67.87\%. But the removal paracetamol decreases slightly by using $25 \mathrm{mg}$ catalyst. Based on the results, the optimum C-N-codoped $\mathrm{TiO}_{2}$ mass for degradation of paracetamol in aqueous solution is $20 \mathrm{mg}$. The increase of catalyst mass can accelerate the paracetamol decay mainly because the higher number of catalysts, the higher surface active side is in photolysis system so that the number of photons absorbed on catalyst surface hinger as well and lead to produce more reactive species like hydroxyl radicals. While large quantities of catalyst will cause agglomeration, sedimentation, declining light scattering, and decreasing penetration of light into the solution thereby decreasing the degradation efficiency (Desale et al, 2013; Yang, Yu, and Ray, 2008). Therefore for the next research uses $20 \mathrm{mg}$ C-N-codoped $\mathrm{TiO}_{2}$ catalyst on paracetamol degradation by photolysis.

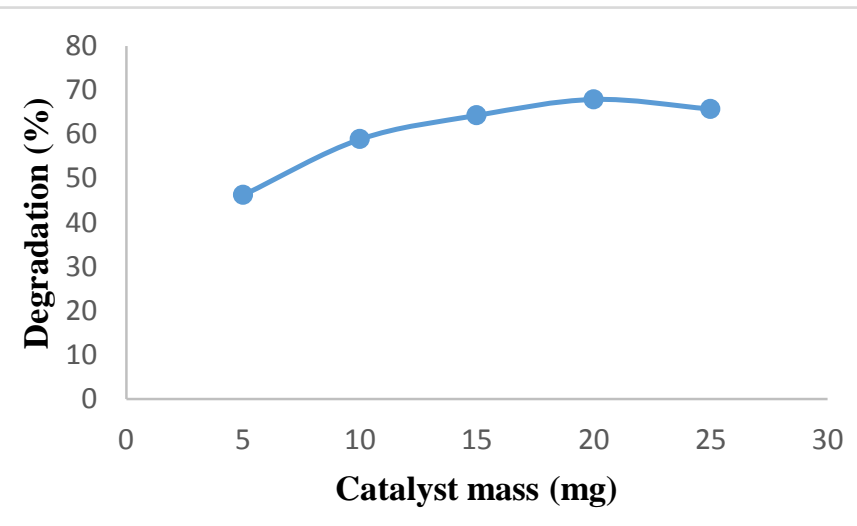

Figure 3. Effect of catalyst mass $(5,10,15,20$ and $25 \mathrm{mg}) \mathrm{C}-\mathrm{N}$-codoped $\mathrm{TiO}_{2}$ on paracetamol degradation for 120 minutes under UV photolysis 

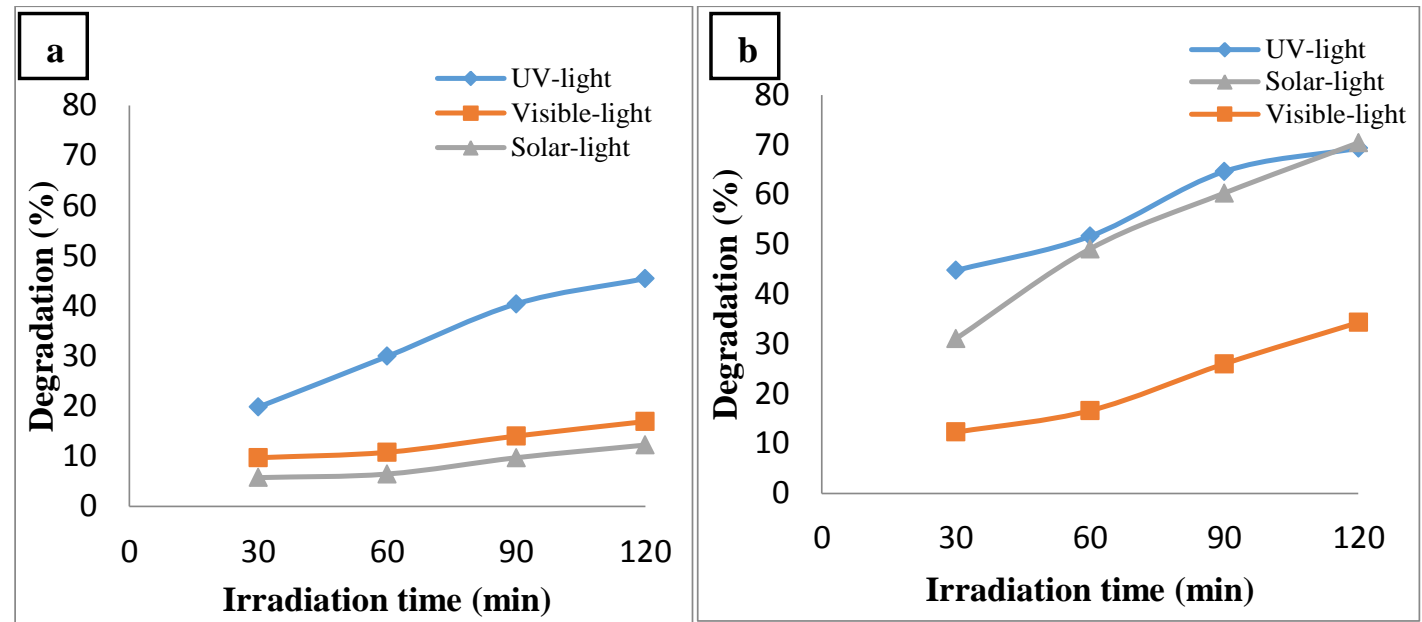

Figure 4. The effect of irradiation time (30, 60, 90, and 120 minutes) on paracetamol degradation (a) without (b) with addition $20 \mathrm{mg} \mathrm{C}-\mathrm{N}$-codoped $\mathrm{TiO}_{2}$ catalyst by photolysis

\section{Effect of irradiation time on paracetamol degradation}

The main factor effecting organic pollutant degradation is irradiation time on photolysis. In this study, the effect of irradiation time (30-120 minutes) with and without adding C-N-codoped $\mathrm{TiO}_{2}$ catalyst. The degradation percentage of paracetamol generally increases by increasing irradiation time.

The results describe photolysis by adding C-N-codoped $\mathrm{TiO}_{2}$ catalyst giving better in efficiency than without catalyst. The degraded paracetamol is found $5.77 \%, 6.49 \%, 9.74 \%$, and $12.27 \%$ under direct solar photolysis for 30-120 minutes shown in Figure 4(a). While the paracetamol efficiency significantly rises to be $31.04 \%, 49.09 \%, 60.28 \%$ and $70.39 \%$ in presence of $20 \mathrm{mg} \mathrm{C}$-N-codoped $\mathrm{TiO}_{2}$ catalyst on the same condition of photolysis shown in Figure 4(b). This results indicate that the C-N-codoped $\mathrm{TiO}_{2}$ catalyst had a considerable role in the photocatalysis process. The contact between $\mathrm{C}-\mathrm{N}$-codoped $\mathrm{TiO}_{2}$ catalyst and photon from energy sources (UV, visible and solar) increases in longer irradiation time, consequently the amount of $\mathrm{OH} \bullet$ radical produced as paracetamol oxidant also increases. When the catalyst is exposed to light, the electron in the photocatalyst will excite from the valence band in to the conduction band which will produce holes in valence band. The hole will react with hydroxides to form $\mathrm{OH} \bullet$, a powerful oxidizing agent to oxidize paracetamol into simple compounds such as $\mathrm{CO}_{2}$ and $\mathrm{H}_{2} \mathrm{O}$ (Safni et al, 2015; Attia, Kadhim, and Hussein, 2008). Within 120 minutes without the addition of catalysts under UV-light $(\lambda=365 \mathrm{~nm})$, visible-light and solar-light irradiation, the percentage degradation is obtained respectively $45.48 \%, 16.96 \%, 12.27 \%$ whereas with the addition of degradation percentage catalyst increases to be $69.31 \%$, $34.295 \%$ and $70.39 \%$.

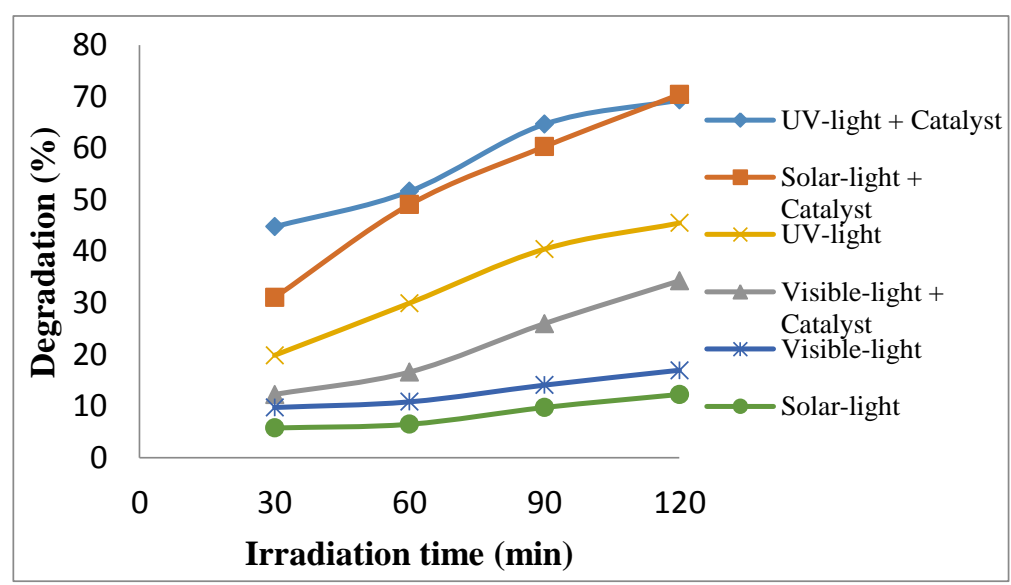

Figure 5. Effect of energy source on paracetamol degradation by photolysis for 120 minutes under $\mathrm{UV}$, visible and solar irradiation with and without catalyst C-N-codoped $\mathrm{TiO}_{2}$ 


\section{Effect of energy source on paracetamol degradation}

The type of light source also affects on paracetamol degradation by photolysis with and without using $\mathrm{C}-\mathrm{N}$-codoped $\mathrm{TiO}_{2}$ catalyst. Paracetamol $4 \mathrm{mg} / \mathrm{L}$ is degraded by 3 types of light sources, UV-light $(\lambda=365 \mathrm{~nm})$, visible-light and solar-light photolysis. The largest degradation percentage of paracetamol under UV-light $(\lambda=365 \mathrm{~nm})$ is $45.48 \%$ and $69.31 \%$ without and with the addition of catalyst for 120 minutes of photolysis. This is due to the intensity generated from UV-light higher and more constant compared to two other energy sources (visible-light and solar-light).

In accordance with the planck's law which says the photon energy is inversely proportional to the wavelength. However, when the photolysis process is added with $20 \mathrm{mg}$ of C-N-codoped $\mathrm{TiO}_{2}$ catalyst, the largest percentage of degradation is reaching $70.39 \%$ under solar-light photocatalysis depicted in Figure 5. These results indicate that the energy provided by the sun can activate the C-N-codoped $\mathrm{TiO}_{2}$ catalyst well so that the photodegradation process of paracetamol becomes more effective. In addition, those titania modification not only can active in higher energy like UV and solar-light but it also can accelerate paracetamol degradation two folds under low energy source (visible-light) with the efficiency $34.29 \%$ in presence C-N-codoped $\mathrm{TiO}_{2}$ compared to absence catalyst on system only $16.96 \%$.

\section{HPLC analysis of paracetamol solution}

Analysis of $4 \mathrm{mg} / \mathrm{L}$ paracetamol solution before and after degradation by photolysis UV using $20 \mathrm{mg} \mathrm{C}-\mathrm{N}$-codoped $\mathrm{TiO}_{2}$ for 120 minutes is analyzed using a high performance liquid

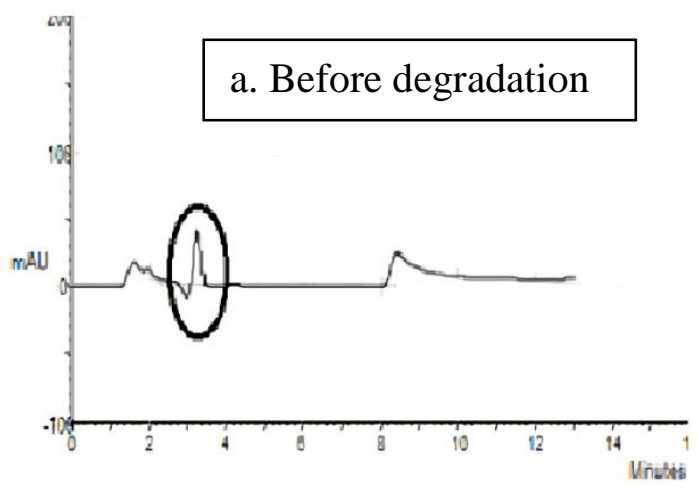

chromatography (HPLC) with UV detector at $257 \mathrm{~nm}$.

The HPLC was packed by $\mathrm{C} 18$ column $(250 \times 4.6 \mathrm{~mm})$. The mobile phase used is acetonitrile and phosphate buffer $\mathrm{pH} 7$ (40: 60 $\mathrm{v} / \mathrm{v})$ and injection volume of paracetamol was $100 \mu \mathrm{m}$ with a flow rate of $1.0 \mathrm{~mL} / \mathrm{min}$. Comparison of the chromatogram peaks between paracetamol solution before and after degradation under UV radiation $(\lambda=365 \mathrm{~nm})$ by photolysis can be shown in Figure 6 . Paracetamol peak appears in chromatogram at retention time $t_{\mathbf{R}}=3.050$ min with absorbance 0.277 . Hence the chromatogram peak decreases with absorbance 0.085 after degradation under UV light $(\lambda=365 \mathrm{~nm})$ photocatalysis for 120 minutes with the addition of the catalyst $\mathrm{C}-\mathrm{N}$-codoped $\mathrm{TiO}_{2}$ indicating that paracetamol has been degraded. The existence of a new peak at retention time $t_{R}=6 \mathrm{~min}$ in chromatogram signifies the possible formation of new compounds as the paracetamol degradation products that need to be analyzed further. Some researchers have reported some paracetamol intermediates such as hydroquinone, benzoquinone, p-nitrophenol, and 1,2,4-trihydroxybenzene and p-aminophenol detected after treatment by photocatalysis using $\mathrm{TiO}_{2}$ catalyst under UV-C light irradiation (Moctezuma, Leyva, Aguilar, Luna, Montalvo, 2012; Jallouli et al, 2014). Paracetamol products found by Yang are formic acid, acetamide, oxamic acid, hydroxy-acetic acid, malonic acid, butenedioic acid, succinic acid, malic acid, hydroquinone, acetamide, $\mathrm{N}$-(2,4-ihydroxyphenyl), acetamide, $\mathrm{N}-(3,4-i h y d r o x y p h e n y l)$ (Yang et al, 2008). While degradation of paracetamol by direct photolysis under UV (254 nm) light irradiation produces 4-aminophenol (4-AP) as a product (Martignac et al, 2013).

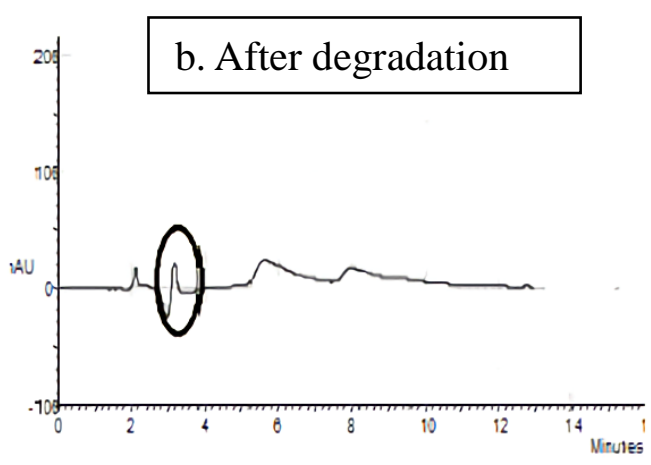

Figure 6. Chromatogram of paracetamol solution (a) before (b) after photocatalysis under UV radiation using $20 \mathrm{mg} \mathrm{C}-\mathrm{N}$-codoped $\mathrm{TiO}_{2}$ catalyst for 120 minutes 


\section{CONCLUSION}

A modification titania, C-N-codoped $\mathrm{TiO}_{2}$, successfully accelerate on paracetamol degradation by photolysis method. The process was effected by catalyst mass, irradiation time and energy sources. The catalyst can active both in high (UV-light) and low energy sources (visible-light). Addition $20 \mathrm{mg} \mathrm{C}-\mathrm{N}$-codoped $\mathrm{TiO}_{2}$ catalyst able to increase paracetamol degradation percentage from $45.48 \%, 16.96 \%$, $12.27 \%$ without using catalyst to be $69.31 \%$, $34.29 \%, 70.39 \%$ by using catalyst under UV-light $(\lambda=365 \mathrm{~nm})$, visible-light and solar-light for 120 minutes respectively.

\section{ACKNOWLEDGEMENT}

We appreciate to DRPM DIKTI for PUPT Grant and all parties who assist in the settlement of this research.

\section{REFERENCES}

Anggraini, D., Safni., Wellia, D. V., Khoiriah. (2016). Degradasi zat warna Direct Red 23 dan Direct Violet melalui proses ozonolisis dan fotolisis dengan sinar UV dan cahaya matahari menggunakan katalis $\mathrm{N}$-Doped $\mathrm{TiO}_{2}$. Jurnal Litbang Industri, 5(2), 123-130.

Attia, A. J., Kadhim, S. H., Hussein, F.H. (2008). Photocatalytic degradation of textile dyeing wastewater using titanium dioxide and zinc oxide, E-J. Chem, 5(2), 219-223.http://dx.doi.org/10.1155/2008/ 876498.

Desale, A., Kamble, S. P. and Deosarkar, M. P. (2013). Photocatalytic degradation of paracetamol using degussa $\mathrm{TiO}_{2}$ photocatalyst. IJCPS, 2, 140-148.

Jallouli, N., Elghniji, K., Trabelsi, Ha., Ksibi, M. (2014). Photocatalytic degradation of paracetamol on $\mathrm{TiO}_{2}$ nanoparticles and $\mathrm{TiO}_{2} /$ cellulosic fiber under UV and sunlight irradiation. Arab. J. Chem, 10, S3640-S3645.

doi: https://doi.org/10.1016/j.arabjc.2014.03. 014.

Martignac, M., Oliveros, E., Maurette, M., Claparolsb, C., Benoit-Marquié F. (2013). Mechanistic pathways of the photolysis of paracetamol in aqueous solution: an example of photo-Fries rearrangement $\dagger$. Photochem. Photobiol.
Sci.,12, $527-535$. doi:10.1039/C2PP25341K.

Mameri, Y., Debbache, N., Benacherine, M. E., Seraghni, N., Sehili, T. (2016). Heterogeneous photodegradation of paracetamol using Goethite $/ \mathrm{H}_{2} \mathrm{O}_{2}$ and Goethite/oxalic acid systems under artificial and natural light. J. Photoch. Photobio. A, 315, 129-137. doi: https://doi.org/10.1016/j.arabjc.2014.03. 014.

Moctezuma, E., Leyva, E., Aguilar, C. A., Luna, R. A., Montalvo, C. (2012). Photocatalytic degradation of paracetamol: Intermediates and total reaction mechanism. J. Hazard. Mater, 243, 130- $138 . \quad$ doi: https://doi.org/10.1016/j.jhazmat.2012.1 0.010

Morikawa, T., Asahi, R., Ohwaki, T., Aoki, K., Taga, Y. (2001). Visible-light photocatalysis in Nitrogen-Doped titanium oxides. Science, 293, 269-271. doi: 10.1126/science.1061051.

Safni, Deliza, Anggraini, D., Dewi, R. S., Ulia, H., Wellia, D. V. (2016). Degradation of Direct Red-81 and Direct Yellow-27 by photolysis with UV-light and solar irradiation using $\mathrm{C}$-N-codoped $\mathrm{TiO}_{2}$. Journal of Chemical and Pharmaceutical Research, 8(12), 30-35.

Safni., Wellia, D.V., Komala, P.S., Reza, A.P. (2015). Degradation of Yellow-GCN by photolysis with UV-light and solar irradiation using C-N-codoped $\mathrm{TiO}_{2}$ catalyst. Journal of Chemical and Pharmaceutical Research, 7, 11, 306-311.

Sebastine, I. M., Wakeman, R. J. (2003). Consumption and environmental hazards of pharmaceutical substances in the UK. Proc. Saf. Environ. Protect, 81, 229-235. doi:

https://doi.org/10.1205/0957582033222 99743.

Xu, Q. C., Wellia, D. V., Yan, S., Liao, D. W., Lim, T. M., Tan T. T. Y. (2011). Enhanced photocatalytic of C-N-codoped $\mathrm{TiO}_{2}$ films prepared via an organic-free approach. J. Hazard. Mater, 188, 172-180. doi: 10.1016/j.jhazmat.2011.01.088.

Yang, L., Yu, L. E., Ray, M. B. (2008). Degradation of paracetamol in aqueous 
solutions by $\mathrm{TiO}_{2}$ photocatalysis. Water research, 42, $3480-3488$. 